OPEN ACCESS

Edited by:

Olga Lage,

University of Porto, Portugal

Reviewed by:

Fabiano Thompson,

Federal University of Rio de Janeiro,

Brazil

Hélène Montanié,

Université de la Rochelle, France

${ }^{*}$ Correspondence:

Tim Lachnit

tlachnit@zoologie.uni.kiel.de

Specialty section:

This article was submitted to

Aquatic Microbiology,

a section of the journal

Frontiers in Microbiology

Received: 03 September 2015

Accepted: 10 December 2015

Published: 08 January 2016

Citation:

Lachnit T, Thomas $T$ and Steinberg $P$

(2016) Expanding our Understanding of the Seaweed Holobiont:

RNA Viruses of the Red Alga Delisea pulchra. Front. Microbiol. 6:1489. doi: 10.3389/fmicb.2015.01489

\section{Expanding our Understanding of the Seaweed Holobiont: RNA Viruses of the Red Alga Delisea pulchra}

\author{
Tim Lachnit ${ }^{1,2 *}$, Torsten Thomas ${ }^{1,3}$ and Peter Steinberg ${ }^{1,4,5}$ \\ ${ }^{1}$ Centre for Marine Bio-Innovation, University of New South Wales, Sydney, NSW, Australia, ${ }^{2}$ Zoological Institute, \\ Christian-Albrechts-University Kiel, Kiel, Germany, ${ }^{3}$ School for Biotechnology and Biomolecular Science, University of New \\ South Wales, Sydney, NSW, Australia, ${ }^{4}$ School of Biological, Earth and Environmental Sciences, University of New South \\ Wales, Sydney, NSW, Australia, ${ }^{5}$ Sydney Institute of Marine Science, Mosman, NSW, Australia
}

Marine seaweeds are holobionts comprised of the macroalgal hosts and their associated microbiota. While the composition of the bacterial component of seaweed microbiomes is increasingly studied, almost nothing is known about the presence, diversity and composition of viruses in macroalgae in situ. In this study, we characterize for the first time the viruses associated with a red macroalga, Delisea pulchra. Using transmission electron microscopy we identified diverse morphotypes of virus-like particles in $D$. pulchra ranging from icosahedral to bacilliform to coiled pleomorphic as well as bacteriophages. Virome sequencing revealed the presence of a diverse group of dsRNA viruses affiliated to the genus Totivirus, known to infect plant pathogenic fungi. We further identified a ssRNA virus belonging to the order Picornavirales with a close phylogenetic relationship to a pathogenic virus infecting marine diatoms. The results of this study shed light on a so far neglected part of the seaweed holobiont, and suggest that some of the identified viruses may be possible pathogens for a host that is already known to be significantly impacted by bacterial infections.

Keywords: viromes, disease, pathogen, seaweed, alga, fungi, macroalga, metaorganism

\section{INTRODUCTION}

Marine seaweeds are colonized by diverse microbial communities (Lachnit et al., 2009, 2011, 2013; Bengtsson et al., 2012; Marzinelli et al., 2015), which interact with their hosts in both positive and negative ways (Matsuo et al., 2005; Fernandes et al., 2011; Campbell et al., 2014). As with other eukaryotes, seaweeds and microorganisms can be considered a "holobiont," an intimately interacting association of microorganisms and their host (Egan et al., 2013). The relationship between the host and its microbiome can be fundamental to the functioning of the host, and when disturbed can result in disease (Case et al., 2011; Willing et al., 2011). This is particularly relevant to marine systems, where diseases can impact whole populations [e.g., seagrass wasting disease (Godet et al., 2008), coral or algal bleaching (Rosenberg et al., 2007; Campbell et al., 2011) or sea star wasting disease (Hewson et al., 2014)], and for which there is evidence for an increasing frequency or intensity of diseases (Harvell et al., 1999). This later observation may be due to increased environmental stress, such as temperature or eutrophication, which are potentially important factors that destabilize the holobiont and make it more susceptible to pathogen infection (Largo et al., 1995). Knowing all the association partners is the first step to understanding 
the health and functional outcomes for marine holobionts, and to the potential consequences of disease in these systems.

Seaweeds are the dominant habitat-forming organisms on temperate rocky reefs, comparable in importance to corals in the tropics (Graham, 2004). In recent years there have been a number of reports of diseases having significant impacts on seaweed populations and communities (Largo et al., 1995; Campbell et al., 2011, 2014). However, in general little is known about seaweed diseases in natural environments and most research done to date on the seaweed holobiont has focused on the identification and composition of surface-associated bacteria. Most of the causative agents identified are thus pathogenic bacteria, or, in a few instances, fungi (Gachon et al., 2010; Egan et al., 2014). The viral component of the seaweed holobiont is in contrast largely unknown.

Viruses are the most abundant entities in the marine environment (Suttle, 2005). They are able to control phytoplankton blooms (Suttle et al., 1990) and are responsible for high mortalities in marine bacteria (Proctor and Fuhrman, 1990). Virome analysis of planktonic microbial communities has shown a great genetic diversity (Angly et al., 2006; Hurwitz and Sullivan, 2013) and has shown that both RNA and DNA viruses are highly abundant in seawater (Culley et al., 2014). However, all of the current knowledge on viruses in seaweeds comes from studies of viruses of two small filamentous brown algae, and in particular two DNA viruses from Ectocarpus sp. and Feldmania sp. (Henry and Meints, 1992; Lanka et al., 1993). Thus the total diversity of viruses present in any seaweed has yet to be characterized, and this is particularly true for RNA viruses (as is generally the case for marine systems (Lang et al., 2009). RNA viruses are of particular interest in this context because these are the most common pathogenic viruses of terrestrial plants (Roossinck, 2012). However, research on RNA viruses in marine systems has been predominantly driven by studies on unicellular algae (Nagasaki et al., 2004; Shirai et al., 2008; Tomaru et al., 2009b, 2012).

In the present study we investigate for the first time the viral community associated with a marine red macroalga, the seaweed Delisea pulchra. D. pulchra is widespread in subtidal communities in temperate and subtropical Australia, where it can form a dominant component of the seaweed community. Interactions between the alga and its complex, surface-associated bacterial communities is mediated by chemical signals (Givskov et al., 1996; Maximilian et al., 1998; Fernandes et al., 2012; Harder et al., 2012). Environmental change can disturb this interaction resulting in bacterial-mediated disease that causes bleaching of the algal thallus (Campbell et al., 2011, 2014; Fernandes et al., 2011; Zozaya-Valdes et al., 2015). While these bacterial processes are increasingly understood, the role of viruses in the D. pulchra holobiont is unexplored. Here, we used transmission electron microscopy (TEM) and virome sequencing to characterize the virome component of D. pulchra, as a first step in understanding the interaction between the host and the viral component of its microbiome. We focus on RNA viruses because of their dominance as pathogens of macrophytes in terrestrial systems (Roossinck, 2012).

\section{MATERIALS AND METHODS}

\section{Collection, Processing, and Microscopy of Virome Samples}

Two individuals (termed here $\mathrm{A}$ and $\mathrm{B}$ ) of $\mathrm{D}$. pulchra were collected at Malabar Beach $\left(33^{\circ} 57^{\prime} 53.9^{\prime \prime} \mathrm{S} 151^{\circ} 15^{\prime} 18.3^{\prime \prime} \mathrm{E}\right)$ in Sydney at $3 \mathrm{~m}$ depth in January 2014 and stored in separated zip lock bags on ice until viral extraction. Each individual was washed in filter-sterilized and autoclaved seawater to remove loosely attached unspecific viral particles from the surrounding seawater. The algal tissue was then homogenized, generating samples that contained both surface-associated and intracellular viruses. Individual algae were then homogenized separately in $100 \mathrm{ml}$ seaweed extraction buffer $(0.1 \mathrm{M}$ Tris base, $0.1 \mathrm{M}$ $\mathrm{KCl}, 52 \mathrm{mM} \mathrm{MgSO} 4,0.4 \mathrm{M} \mathrm{NaCl}, 10 \mathrm{mM} \mathrm{CaCl}_{2}, 0.01 \mathrm{M}$ sodium sulphite, $\mathrm{pH}$ 7.6) in a tissue homogenizer for $5 \mathrm{~min}$ at $4^{\circ} \mathrm{C}$. The homogenate was pressed through cheesecloth and further purified by low speed centrifugation at $2,000 \times g$ for 2 min followed by a second centrifugation step at $10,000 \times g$ for $10 \mathrm{~min}$. The supernatant was passed through a $0.45 \mu \mathrm{m}$ filter and viral particles were precipitated by the addition of $10 \%(\mathrm{w} / \mathrm{v})$ PEG 8,000 overnight. Viral particles were pelleted by centrifugation at $7,600 \times g$ for $30 \mathrm{~min}$ and re-suspended in VR buffer $\left(50 \mathrm{mM}\right.$ Tris, $8 \mathrm{mM} \mathrm{MgSO}_{4}, 0.4 \mathrm{M} \mathrm{NaCl}$, $0.01 \mathrm{M}$ sodium sulphite, $\mathrm{pH}$ 7.6) overnight. Cellular debris was removed by low speed centrifugation at $7,600 \times g$ for $10 \mathrm{~min}$. The viral containing supernatant was then further purified by density gradient ultracentrifugation. For this the viral suspension was loaded onto a $10-40 \%$ Optiprep gradient and centrifuged in a Beckman SW 41 ti swinging bucket rotor at $28,000 \mathrm{rpm}$ for $2 \mathrm{~h}$. After ultracentrifugation one distinct viral band was observed in both samples. These viral bands were removed separately by syringe, diluted $1: 3$ in VR buffer and pelleted by centrifugation at 28,000 rpm for $2 \mathrm{~h}$. Viruses were re-suspended in $200 \mu \mathrm{l} \mathrm{VR}$ buffer without sodium sulphite. The presence of viral particles was checked by epifluorescence microscopy according to the protocol developed by Thurber et al. (2009). Viral particles were further characterized morphologically by negative staining in $2 \%(\mathrm{w} / \mathrm{v})$ aqueous uranyl acetate and visualized by TEM using a FEI Technai G2 20 TEM at $200 \mathrm{kV}$ and a magnification of 40,000-100,000. Images were acquired by a BM Eagle digital camera and Image J $1.48 \mathrm{v}$ (Schneider et al., 2012) was used to determine the diameter of viral particles and to improve brightness and contrast.

\section{Viral RNA Preparation}

Two-hundred microlitres of purified and re-suspended viral particles per sample prepared as above were used for RNA extraction. Viral RNA was extracted in SDS-extraction buffer (1\% SDS; $200 \mathrm{mM}$ Tris; $50 \mathrm{mM}$ EDTA pH 7.5) in the presence of $1 \%(\mathrm{w} / \mathrm{v})$ polyvinylpyrrolidone (mol wt 40,000), 1\% 2mercaptoethanol and proteinase $\mathrm{K}(0.5 \mathrm{mg} / \mathrm{ml})$ at $37^{\circ} \mathrm{C}$ for $30 \mathrm{~min}$, followed by a second incubation step at $56^{\circ} \mathrm{C}$ for $15 \mathrm{~min}$. Twice the amount of RNA-extraction buffer $(150 \mathrm{mM}$ Tris, 75 mM EDTA, 2.6 M NaCl, 2.6\% cetyltrimethylammonium 
bromide (CTAB); 1\% 2-mercaptoethanol; $\mathrm{pH}$ 7.5) was added and samples were incubated for another $15 \mathrm{~min}$ at $56^{\circ} \mathrm{C}$. An equal volume of chloroform:isoamyl alcohol (24:1) was then added to the warm solution, mixed thoroughly and centrifuged at $12,000 \times g$ at room temperature for $5 \mathrm{~min}$. The chloroform:isoamyl alcohol extraction of the supernatant was repeated three times to remove contaminating polysaccharides and proteins. Finally, supernatant was transferred into a new tube and the nucleic acids were precipitated by the addition of 0.7 volume of isopropanol. After an incubation step at $-20^{\circ} \mathrm{C}$ for $2 \mathrm{~h}$ nucleic acids were pelleted by centrifugation at $14,000 \times g$ at $4^{\circ} \mathrm{C}$ for $20 \mathrm{~min}$. The pellet was washed with $75 \%(\mathrm{v} / \mathrm{v})$ ethanol, air dried and dissolved in $30 \mu \mathrm{l}$ moleculargrade water. DNA was digested with the TURBO ${ }^{\mathrm{TM}}$ DNAse (Life Technology) according to the manufacture's protocol. RNA was purified by column purification using the Quick-RNA ${ }^{\mathrm{TM}}$ MiniPrep kit (Zymo Research). The TruSeq stranded-RNA preparation kit (Illumina) was used for reverse transcription and cDNA library preparation. Sequencing was conducted on a MiSeq platform (Illumina) at the Ramaciotti Centre for Genomics (University of New South Wales, Sydney, NSW, Australia).

\section{Sequence Processing and Analysis}

Sequence reads were trimmed and adaptors removed using Trimmomatic V0.32 (Bolger et al., 2014) and assembled using SPAdes 3.1.1 (Bankevich et al., 2012). Contigs were compared to the nucleotide sequence database (nt) of the National Centre for Biotechnology Information (NCBI) using blastn to identify contaminating ribosomal sequences. Contigs with an alignment length $>75 \%$ of the query length and an $e$-value $<10^{-4}$ were classified as contaminations and removed by Deconseq 0.4.3 (Schmieder and Edwards, 2011) from the sequence data. Contigs were finally classified into families using blastx and tblastx against the $\mathrm{nr}$ and refseq viral database (Pruitt et al., 2012) with an $e$-value cut-off smaller $10^{-5}$. The coverage of each contig was used to get a relative quantitative measure of the viral abundance (Figure 3). All partial or complete viral sequences have been submitted to the GenBank database under the accession no. LIKW00000000 (individual a) and LIKX000000000 (individual b).

\section{Phylogenetic Analysis}

Reference sequences of the RNA-dependent RNA polymerase (RdRp) from different viruses were obtained from NCBI. Multiple alignment of amino acid sequences of the RdRp were constructed using ClustalW implemented in BioEdit 7.2.5 (Thompson et al., 1994; Hall, 1999). Phylogenetic trees were calculated based on the conserved regions of the RdRp using Mega 6.0 (Tamura et al., 2013). Phylogenetic trees were calculated using the maximum likelihood method with partial position deletion, a Poisson model and 1000 bootstrap replications. RdRp sequences analyzed in the phylogenetic tree have been submitted to GenBank database and can be found under the accession numbers Totivirus: KT455444-KT455461 and Picornaviridae KT455462-KT455464.

\section{RESULTS}

Transmission electron microscopy (TEM) of negative-stained virus-like particles (VLPs) revealed in both samples a range of morphotypes (Figure 1), including icosahedral (A, D, and E), bacilliform to coiled pleomorphic (B and C) VLPs as well as bacteriophages (F). We observed two size classes of icosahedral viral particles one with a diameter of $40 \mathrm{~nm}$ (Figures 1A,D) and one with a diameter of $30 \mathrm{~nm}$ (see assemblage of viral particles Figure 1E). The pleomorphic forms observed under TEM (Figures 1B,C), while virus-like, may also have been membrane vesicles originating from the homogenized algal tissue.

After removal of contaminating sequences, 267,372 reads of individual A could be assembled into 509 contigs. Based on blastx results 102 could be assigned to viruses. Individual B with 294,226 cleaned reads resulted in 369 contigs, for which 41 viral hits were found (Table 1). Sequence analysis revealed that both individuals contained single- and double-stranded RNA viruses. ssRNA viruses accounted for 18 and $10 \%$ of the viral community compared to 82 and $90 \%$ dsRNA viruses for individual A and B, respectively (Figure 2).

Most of the ssRNA viruses identified in this study showed highest sequence similarity (based on blastx results) to viruses known to infect unicellular Heterokontophyta, such as Heterosigma akashiwo RNA virus and Chaetoceros sp. RNA virus. A few viruses were closely related to viruses known to infect terrestrial plants, such as Cucurbitaceae. The most dominant ssRNA virus of $D$. pulchra showed highest sequence similarity to the diatom-infecting Asterionellopsis glacialis RNA virus (Agla RNA virus). The almost full-length genome sequence of this D. pulchra RNA virus with a length of 9581 bp has been submitted to GenBank under the accession number KT455464. Similar to the Agla RNA virus the D. pulchra RNA virus encodes two major polyproteins; one replication associated and one structural polyprotein (Figure 3A). Protein domain analysis via SMART (Simple Modular Architecture Research Tool; Letunic et al., 2015) revealed that the two polyproteins of both viruses are of similar architecture and amino acid composition (29 and 23\% sequence similarity for the replication associated polyprotein and the structural polyprotein, respectively; Figures $3 B, C$ ). Within conserved domains of the polyprotein similarity reaches values of $50 \%$ for the $\mathrm{RdRp}$ and $46 \%$ for the structural domain Dcistrvp4. This virus could be detected in both individuals and accounted for $7-14 \%$ of the viral composition. Analysis based on the amino acid sequence of the RdRp showed that this D. pulchra RNA virus distinctly clusters with environmental sequences (GenBank accession numbers AY285750-AY285768) generated from geographically and seasonally diverse samples of marine

TABLE 1 | Summary table of Delisea pulchra RNA viromes generated for two algal individuals $A$ and $B$.

\begin{tabular}{lll}
\hline & Individual A & Individual B \\
\hline Total numbers of reads & 267,372 & 294,226 \\
Number of contigs & 509 & 369 \\
Viral sequences & $20 \%$ & $11 \%$ \\
Unknown sequences & $80 \%$ & $89 \%$
\end{tabular}




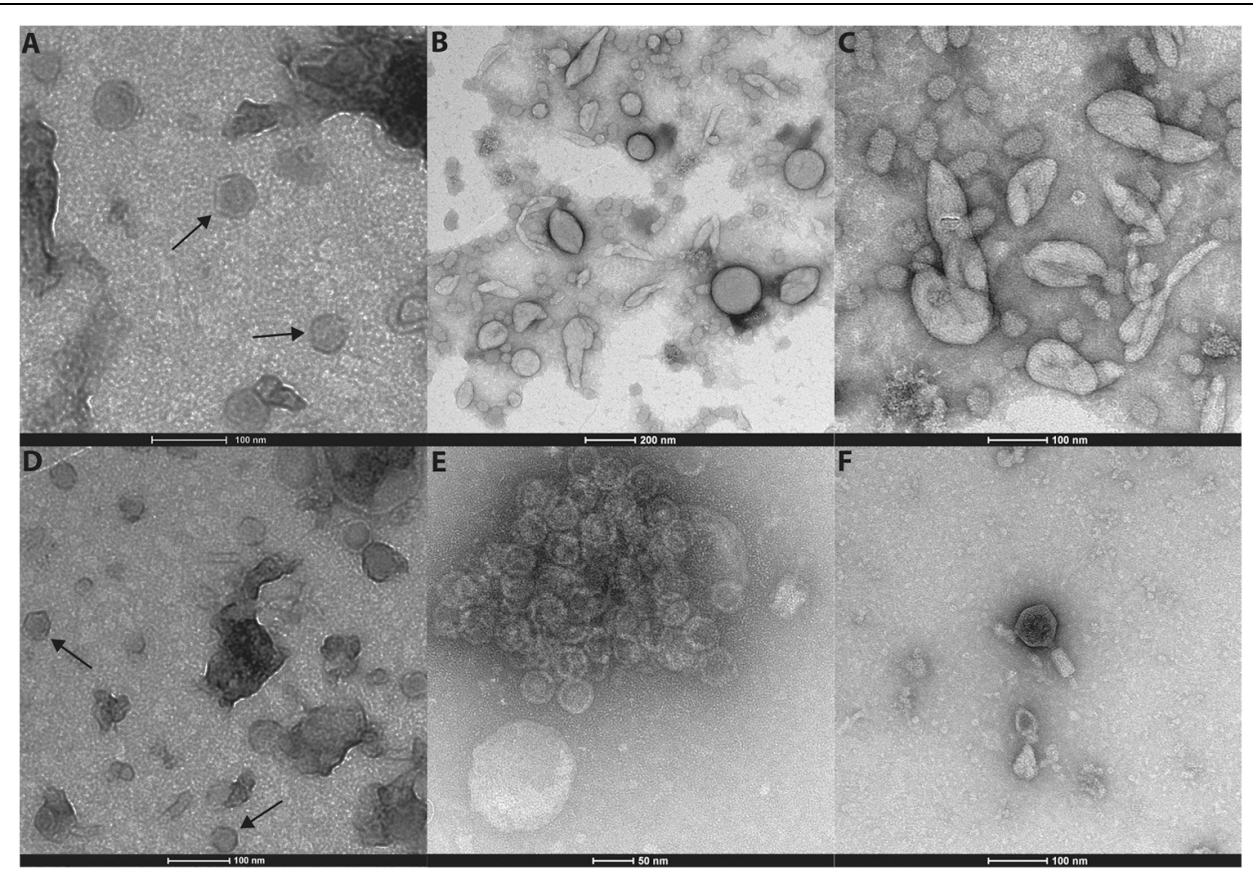

FIGURE 1 | Different morphotypes of virus like particles could be observed in both individuals. Icosahedral viral particles with a diameter of 40 nm (A,D) and another size class with a diameter of $30 \mathrm{~nm}$ (E). Bacilliform to coiled pleomorphic forms (B,C) were detected as well as bacteriophages (F).

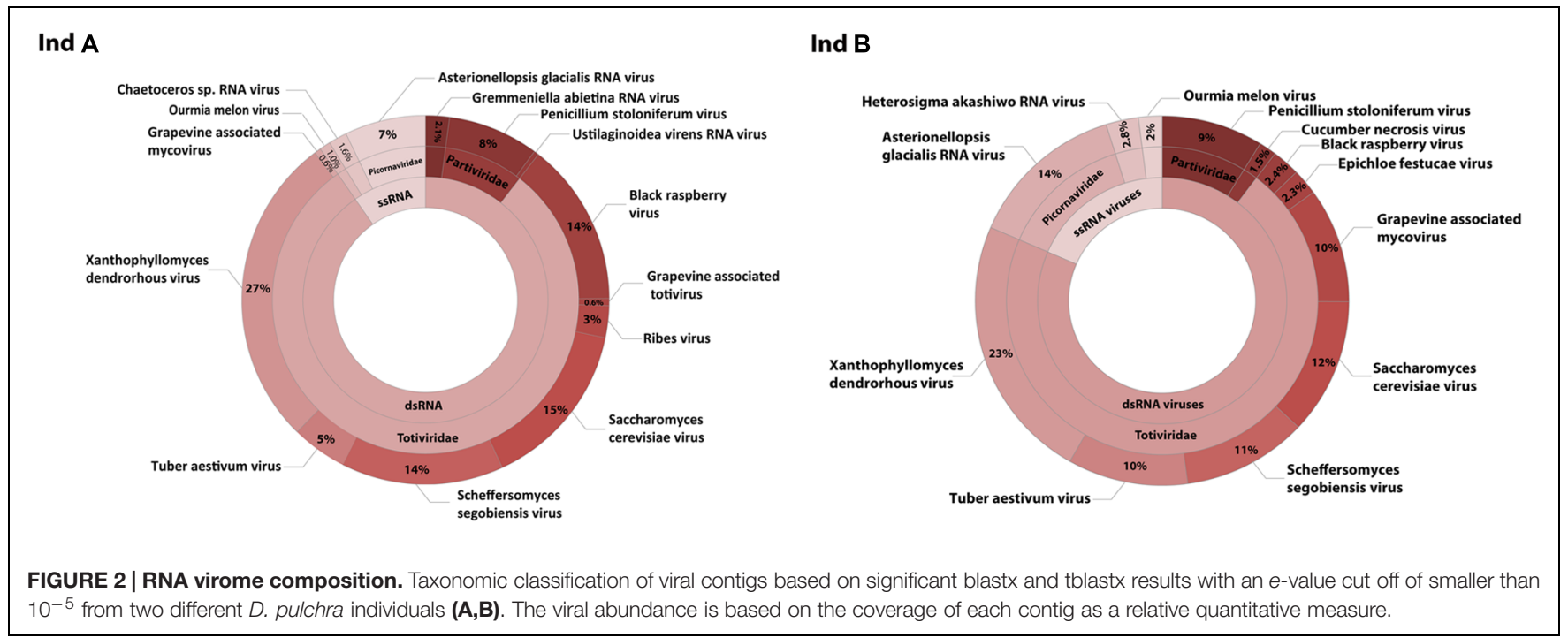

virioplankton communities (Culley et al., 2003) and with other viruses isolated from marine diatoms (Figure 4).

In addition, we discovered a diverse group of genetically distinct dsRNA viruses. These dsRNA viruses are taxonomically affiliated with the families Partitiviridae and Totiviridae (Figure 2). The relative abundance of Partitiviridae was comparable in both individuals and showed only a low diversity, essentially being dominated by a vius with similarity to Penicillium stoloniferum virus. In contrast, for the Totiviridae we detected more taxonomic diversity at lower levels. Comparison between the two different individuals showed that some viruses with similarity to Xanthophyllomyces dendrorhous virus, Scheffersomyces segobiensis virus, and Saccharomyces cerevisiae virus had relatively consistent abundances, while other viruses with similarity to Grapevine associated mycovirus (0.6-10\%), Black raspberry virus (2.4-14\%), and Tuber aestivum virus (5$10 \%)$ were more variable between both individuals. Phylogenetic analysis based on the RdRp clearly shows that $D$. pulchra's associated Totiviridae form multiple, distinct clusters within the genus Totivirus (Figure 5).

Cross-tblastx comparison of $D$. pulchra viromes with other published marine RNA viromes of the virioplankton community 


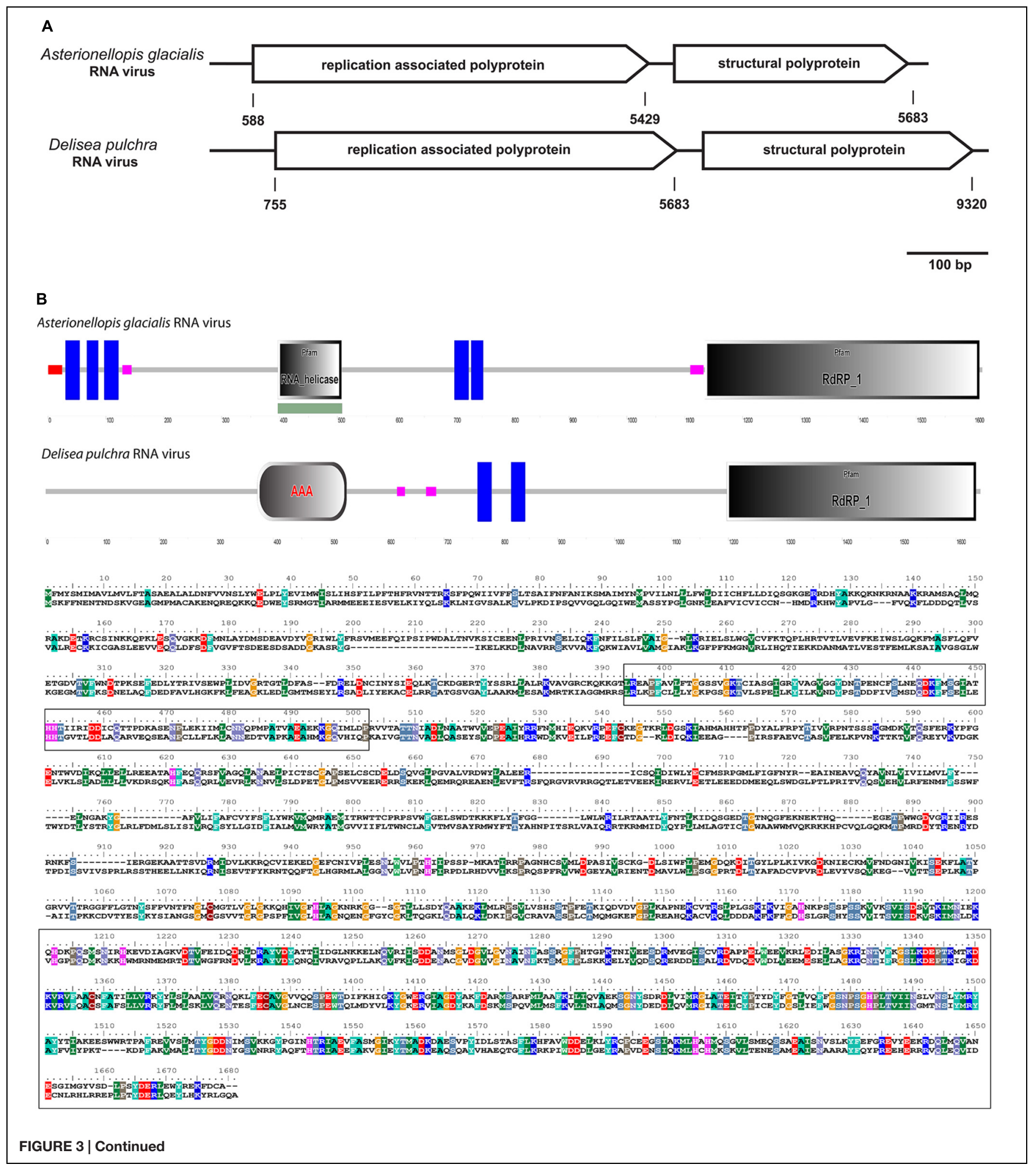

of the Strait of Georgia, Canada (Culley et al., 2014) showed that $8-20 \%$ of the virioplankton sequences are shared with D. pulchra viromes based on an e-value cut-off smaller $10^{-5}$. The majority of shared sequences belonged to the Picornavirales $64-87 \%$ and $5-6 \%$ were similar to other ssRNA viruses of D. pulchra. $7-28 \%$ of the shared sequences of the virioplankton community showed best blast hits to unknown sequences of $D$. pulchra viromes and $0.03-2.4 \%$ to dsRNA viruses of the Totiviridae identified in D. pulchra viromes. 


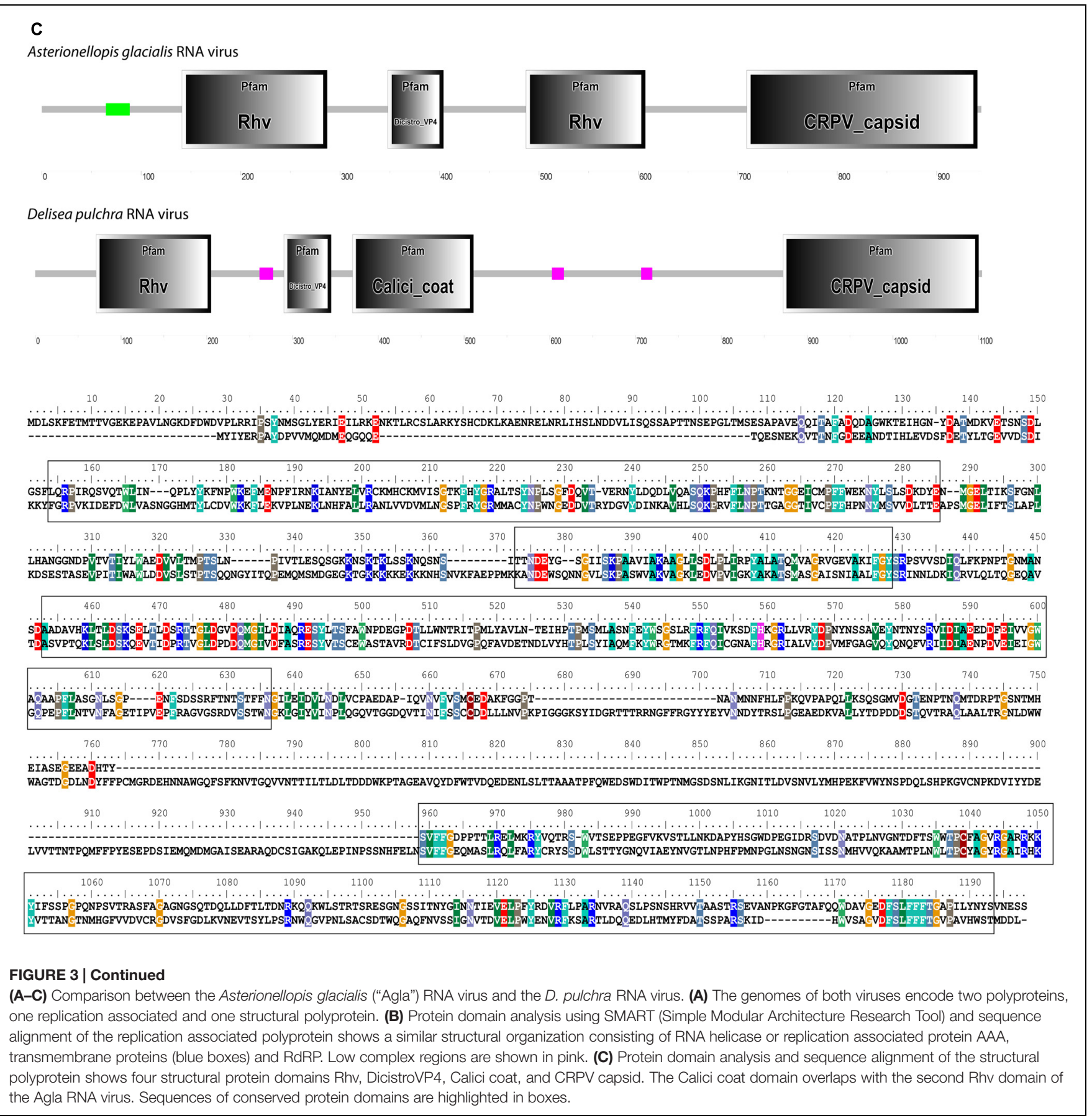

\section{DISCUSSION}

The surface of marine seaweeds are colonized by diverse bacterial communities (Lachnit et al., 2011). This association between host and microorganisms is expected to play an important role for the stability of the seaweed holobiont. In the present study we focussed on viruses associated with the red alga D. pulchra in order to broaden our understanding of the interaction and diversity of the seaweed holobiont, and ultimately to move toward an understanding of the role that viruses may play in disease of these seaweeds. To our knowledge, this is the first isolation of RNA viruses from seaweeds and description of entire macroalgal viromes. Because of the methods we used, these viromes include surface-associated as well as intracellular viruses, both of which may be important in the ecology of this holobiont.

There were a number of methodological challenges in extracting the virome from D. pulchra. During the homogenisation process of algal tissue different compounds are co-extracted along with the viruses, such as polysaccharides 


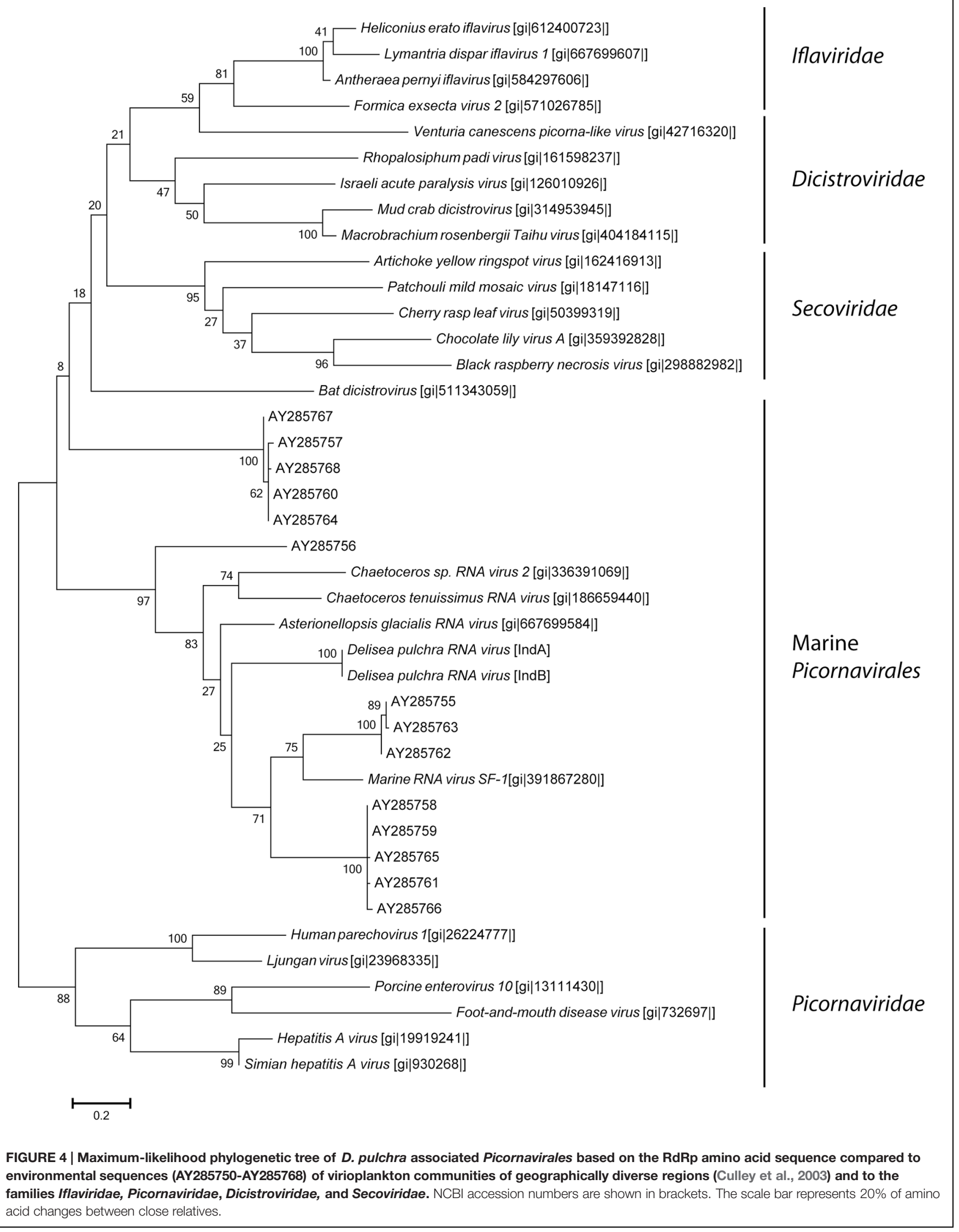




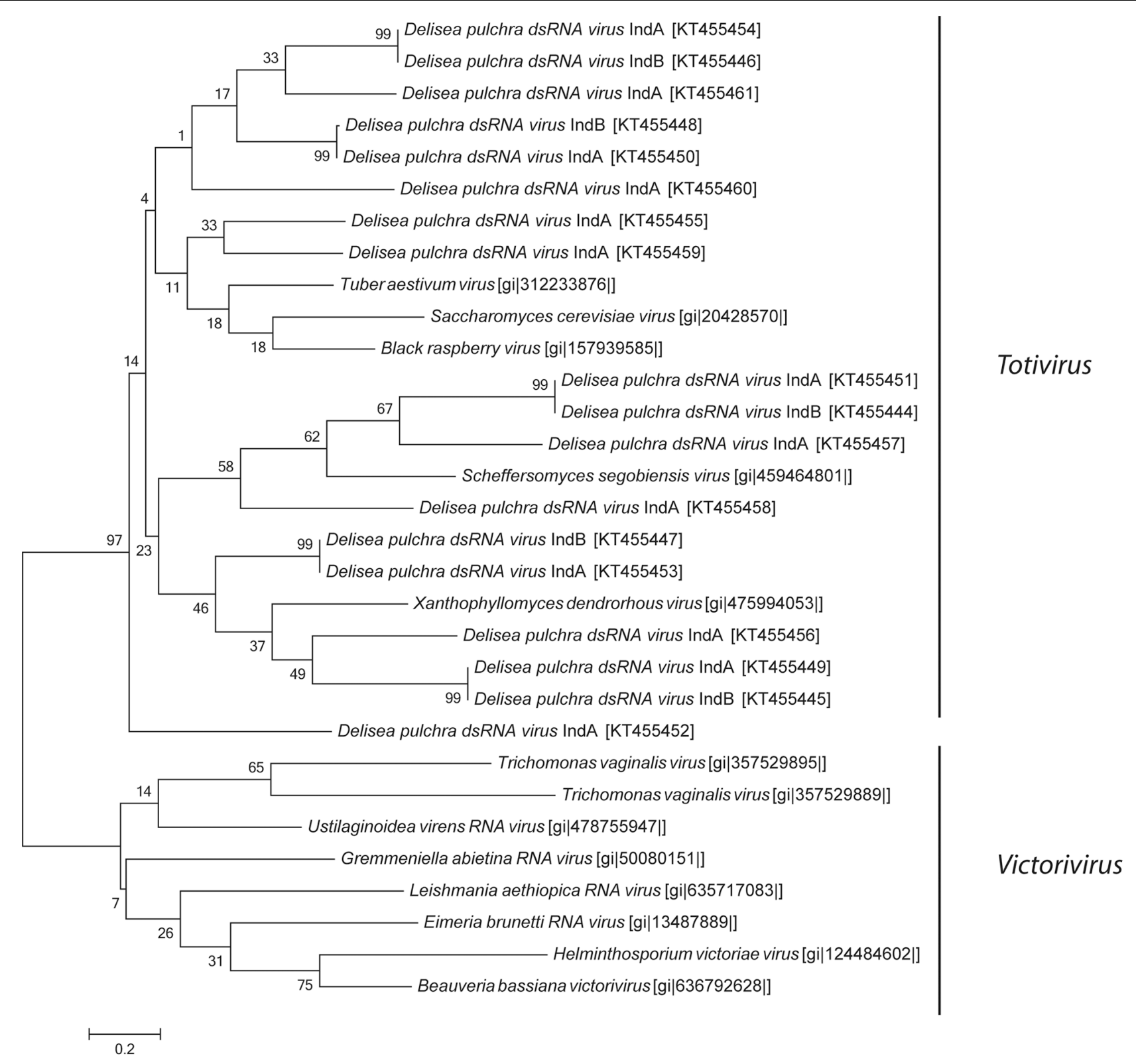

FIGURE 5 | Maximum-likelihood phylogenetic tree of D. pulchra associated Totiviridae based on the RdRp amino acid sequence compared to the genus Victorivirus and Totivirus. NCBI accession numbers are shown in brackets. The scale bar represents $20 \%$ of amino acid changes between close relatives.

and secondary metabolites (Thomas and Kim, 2013) that interfere with the isolation and purification of viruses. By using different purification methods, such as filtration, low-speed centrifugation, gradient ultracentrifugation in combination with a stabilizing extraction buffer and the use of an iso-osmotic density gradient medium, we were able to isolate viruses from the marine seaweed $D$. pulchra.

The most dominant ssRNA virus detected in this study belonged to the order Picornavirales with its closest phylogenetic relation to A. glacialis ("Agla”) RNA virus, which infects marine diatoms and induces cell lysis (Tomaru et al., 2012). Similar to the morphology of the AglaRNA virus, we observed icosahedral viral particles by TEM. These non-enveloped viral particles were small with a diameter of $30 \mathrm{~nm}$ which match the typical capsid size of Picornavirales (Hulo et al., 2011). Together with other diatom infecting marine viruses and environmental sequences from diverse marine virioplankton viromes, this $D$. pulchra RNA virus forms a distinct cluster within the Picornavirales, which neighbors the plant infecting viruses of the family Secoviridae. Whether or not these marine RNA viruses form a new family of marine alga infecting viruses or belong to the 
Secoviridae requires further investigation and the verification of the common properties of Secoviridae outlined by Sanfaçon et al. (2009). In previous studies it has been shown that Picornalike viruses are not only pathogens of animals, plants and insects in terrestrial environments, but can also be found at high abundances within the viral seawater community (Steward et al., 2013). Phylogenetic analysis based on PCR amplified RdRp sequences revealed a high phylogenetic diversity suggesting several different new families of Picorna-like viruses in the plankton viral community (Culley et al., 2003; Gustavsen et al., 2014). The isolation of the D. pulchra RNA virus is consistent with the broad host-range of Picornavirales which are known to infect terrestrial plants as well as humans (Tuthill et al., 2010) and they may have a strong impact on D. pulchra seaweed habitats similar to their proposed important role in structuring phytoplankton communities (Gustavsen et al., 2014).

Virome sequencing revealed that D. pulchra also contains a diverse group of dsRNA viruses affiliated with the genus Totivirus. So far, dsRNA viruses, relative to ssRNA viruses, have been underrepresented in seawater samples (Culley et al., 2006) and only a few dsRNA virus have been described from the marine plankton community, e.g., MpRNAV virus infection of the protist Micromonas pulsilla (Brussaard et al., 2004). Members of the Totivirus have a similar morphology compared to the Picornavirales. Viruses of the genus Totivirus are nonenveloped and feature an icosahedral symmetry. In contrast to Picornavirales, Totiviruses are larger with a diameter of $40 \mathrm{~nm}$ (Hulo et al., 2011). This agrees with the two different size classes of icosahedral viruses we observed by TEM. Totiviruses are known to infect fungi that are pathogenic to plants. The observation that $D$. pulchra is associated with viruses that are so far only known to infect fungi may point either to the presence of fungi in the holobiont D. pulchra or to a diverse group of marine Totivirus that are able to infect seaweeds. Viruses in the genus Totivirus predominantly infect smut fungi (Ghabrial and Suzuki, 2009). Smut fungi are also present in the marine environment and it has been demonstrated that they may cause infective disease in marine red alga (Williams et al., 2014). We could demonstrate that sequences of Totiviruses are also present in virioplankton communities, but compared to ssRNA viruses, particularly those of the order Picornavirales, these sequences are highly underrepresented. This might be explained by the transmission of Totiviruses, which are transmitted from cell to cell by cytoplasmatic exchange, sporogenesis or hyphal anastomosis allowing viral transmission from host to host without budding (Hulo et al., 2011).

RNA viruses represent an essential part of the marine viral community reaching or even exceeding the abundance of DNA viruses in coastal waters (Steward et al., 2013). They are the most common viral pathogens of land plants, and RNA viruses are thought to control phytoplankton blooms, although the number of studies demonstrating infection by RNA viruses of marine microorganisms is still small. For example, ssRNA viruses (HaRNA virus) infect the bloom forming alga $H$. akashiwo (Nagasaki et al., 1999) and HcRNA virus controls another red tide producing dinoflagellate Heterocapsa circularisquama (Tomaru et al., 2009a). Several ssRNA have also been shown to infect diatoms such as Chaetoceros (Shirai et al., 2008; Tomaru et al., 2009b, 2011) and one dsRNA has been identified in the marine environment that infects marine microalga (Brussaard et al., 2004). However, these studies represent only a snapshot of viruses compared to the high diversity of viruses that have been identified by virome sequencing of the virioplankton community. Up to now only a limited part of the virioplankton community can be linked to their eukaryotic host, such as microalgae.

We know even less about the viromes of macroalga with the lack of sequence data for macroalgal viruses in public databases significantly constraining the analysis of our data. Most of the viral sequence data in public databases are from pathogens or domesticated plants. The only viruses known from multicellular marine alga are the Ectocarpus siliculosus virus (Lanka et al., 1993) and Feldmannia sp. virus (Henry and Meints, 1992), both of which are DNA viruses. For this reason the sequence similarities of RNA viruses detected in this study represent only relatively distant relatives to known or characterized viruses (see Figures 4 and 5). The observed sequence similarities to viruses known to infect Heterokontophyta or diatoms therefore does not strictly speak to these organisms being the host of the viruses we have isolated, e.g., as epiphytes on D. pulchra. While we cannot exclude that some of the isolated viruses might be derived from surfaceassociated epiphytes, we took great care to select individuals that were visually free from fouling organisms and cleaned the algal surface to remove loosely attached contaminations from planktonic organisms. We thus believe that the RNA virus, found here indeed directly interacts with D. pulchra, which is further supported by the many taxonomic groups found consistently from both individuals. However, due to the method used in this study to isolate viruses we do not know how the viruses may be localized within the seaweed holobiont. They might be surface-associated or originate from inside the algal tissue.

Delisea pulchra is arguably one of the best known seaweed holobionts, but to date the focus on the microbiome of this alga has been limited to the bacterial (or archaeal) component. This microbiome is complex (Fernandes et al., 2012) and when disrupted causes a bleaching disease that significantly affects populations of this seaweed (Campbell et al., 2011, 2014; Case et al., 2011; Fernandes et al., 2012). Given the association between the viruses identified here and known plant pathogens, it is interesting to speculate that these viruses may also contribute to disease of these seaweeds. For example, temperature modulates infection of D. pulchra by bacteria (Case et al., 2011), and environmental conditions can also influence hostviral interactions (Larsen et al., 2008; Vega Thurber et al., 2008). Viral infection can also modulate the host derived defense, such as terpenoid synthesis and facilitate secondary infection (Luan et al., 2013; de Oliveira et al., 2015). Functional analysis of viral sequences could be one potential tool to identify such interaction, but unfortunately we did not detect any known candidate gene that might interact with the host. The only proteins that we found were replication associated or structural proteins of the isolated RNA viruses. 
Moreover, in addition to the eukaryotic viruses identified by RNA analysis, we also observed bacteriophages by TEM (these were not detected in our sequencing, but RNA containing bacteriophages are less common than those containing DNA (Bollback and Huelsenbeck, 2001; Mertens, 2004). Such bacteriophages might infect bacteria on the surface of the alga, thereby changing the alga-bacterial interactions for this holobiont in unknown ways and may act as part of the holobiont immune system (Barr et al., 2013, 2014). In addition, the presence of viruses that putatively infect fungi suggests that they may control the abundance of other components of the microbiome, such as fungi. It is also interesting to draw parallels between the antibacterial compounds of $D$. pulchra (Givskov et al., 1996) and known antiviral compounds of red algae. For example, terpenes (de Oliveira et al., 2015), lectins (Takebe et al., 2013), bromophenols (Kim et al., 2011), or polysaccharides (Wang et al., 2012) have shown to possess strong antiviral activity against human pathogenic viruses. The observation in this study that marine algae are associated with a diverse viral community highlights the ecological relevance of seaweed to produce antiviral compounds. Knowing the interacting viral partners of seaweed may enable a more target-orientated drug discovery of antiviral compounds.

\section{REFERENCES}

Angly, F. E., Felts, B., Breitbart, M., Salamon, P., Edwards, R. A., Carlson, C., et al. (2006). The marine viromes of four oceanic regions. PLoS Biol. 4:e368. doi: 10.1371/journal.pbio.0040368

Bankevich, A., Nurk, S., Antipov, D., Gurevich, A. A., Dvorkin, M., Kulikov, A. S., et al. (2012). SPAdes: a new genome assembly algorithm and its applications to single-cell sequencing. J. Comput. Biol. 19, 455-477. doi: $10.1089 / \mathrm{cmb} .2012 .0021$

Barr, J. J., Auro, R., Furlan, M., Whiteson, K. L., Erb, M. L., Pogliano, J., et al. (2013). Bacteriophage adhering to mucus provide a non-host-derived immunity. Proc. Natl. Acad. Sci. U.S.A. 110, 10771-10776. doi: 10.1073/pnas.1305 923110

Barr, J. J., Youle, M., and Rohwer, F. (2014). Innate and acquired bacteriophage-mediated immunity. Bacteriophage 3:e25857. doi: 10.4161/bact. 25857

Bengtsson, M. M., Sjøtun, K., Lanzén, A., and Ovreås, L. (2012). Bacterial diversity in relation to secondary production and succession on surfaces of the kelp Laminaria hyperborea. ISME J. 6, 2188-2198. doi: 10.1038/ismej.2012.67

Bolger, A. M., Lohse, M., and Usadel, B. (2014). Trimmomatic: a flexible trimmer for Illumina sequence data. Bioinformatics 30, 2114-2120. doi: 10.1093/bioinformatics/btu170

Bollback, J. P., and Huelsenbeck, J. P. (2001). Phylogeny, genome evolution, and host specificity of single-stranded RNA bacteriophage (family Leviviridae). J. Mol. Evol. 52, 117-128.

Brussaard, C. P. D., Noordeloos, A. A. M., Sandaa, R.-A., Heldal, M., and Bratbak, G. (2004). Discovery of a dsRNA virus infecting the marine photosynthetic protist Micromonas pusilla. Virology 319, 280-291. doi: 10.1016/j.virol.2003.10.033

Campbell, A. H., Harder, T., Nielsen, S., Kjelleberg, S., and Steinberg, P. D. (2011). Climate change and disease: bleaching of a chemically defended seaweed. Glob. Chang. Biol. 17, 2958-2970. doi: 10.1111/j.1365-2486.2011.02456.x

Campbell, A. H., Vergés, A., and Steinberg, P. D. (2014). Demographic consequences of disease in a habitat-forming seaweed and impacts on interactions between natural enemies. Ecology 95, 142-152. doi: 10.1890/130213.1

\section{CONCLUSION}

This study shows that a large diversity of eukaryotic viruses exists in the marine seaweed D. pulchra. This finding argues that the interactions between the host and its associated viruses should be considered for future studies of marine holobionts. Viruses could play a key role in modulating both positive and negative interactions for the macroalgal host and be an important factor in ensuring the stability of the seaweed holobiont.

\section{AUTHOR CONTRIBUTIONS}

Conceived and designed the experiments: TL, TT, and PS performed the experiments: TL analyzed the data: TL Contributed reagents/materials/analysis tools:TT and PS wrote the paper: TL, TT, and PS.

\section{ACKNOWLEDGMENTS}

The research was supported by the German science foundation (DFG-La 297 8/1-1), a DFG reintegration grant and the Australian Research Council.

Case, R. J., Longford, S. R., Campbell, A. H., Low, A., Tujula, N., Steinberg, P. D., et al. (2011). Temperature induced bacterial virulence and bleaching disease in a chemically defended marine macroalga. Environ. Microbiol. 13, 529-537. doi: 10.1111/j.1462-2920.2010.02356.x

Culley, A. I., Lang, A. S., and Suttle, C. A. (2003). High diversity of unknown picorna-like viruses in the sea. Nature 424, 1054-1057. doi: 10.1038 /nature01886

Culley, A. I., Lang, A. S., and Suttle, C. A. (2006). Metagenomic analysis of coastal RNA virus communities. Science 312, 1795-1798. doi: 10.1126/science. 1127404

Culley, A. I., Mueller, J. A., Belcaid, M., Wood-Charlson, E. M., Poisson, G., and Steward, G. F. (2014). The characterization of RNA viruses in tropical seawater using targeted PCR and metagenomics. MBio 5:e01210. doi: 10.1128/mBio.01210-14

de Oliveira, L. S., Tschoeke, D. A., de Oliveira, A. S., Hill, L. J., Paradas, W. C., Salgado, L. T., et al. (2015). New Insights on the terpenome of the red seaweed Laurencia dendroidea (Florideophyceae. Rhodophyta). Mar. Drugs 13, 879-902. doi: $10.3390 / \mathrm{md} 13020879$

Egan, S., Fernandes, N. D., Kumar, V., Gardiner, M., and Thomas, T. (2014). Bacterial pathogens, virulence mechanism and host defence in marine macroalgae. Environ. Microbiol. 16, 925-938. doi: 10.1111/1462-2920. 12288

Egan, S., Harder, T., Burke, C., Steinberg, P., Kjelleberg, S., and Thomas, T. (2013). The seaweed holobiont: understanding seaweed-bacteria interactions. FEMS Microbiol. Rev. 37, 462-476. doi: 10.1111/1574-6976.12011

Fernandes, N., Case, R. J., Longford, S. R., Seyedsayamdost, M. R., Steinberg, P. D., Kjelleberg, S., et al. (2011). Genomes and virulence factors of novel bacterial pathogens causing bleaching disease in the marine red alga Delisea pulchra. PLoS ONE 6:e27387. doi: 10.1371/journal.pone.0027387

Fernandes, N., Steinberg, P., Rusch, D., Kjelleberg, S., and Thomas, T. (2012). Community structure and functional gene profile of bacteria on healthy and diseased thalli of the red seaweed Delisea pulchra. PLoS ONE 7:e50854. doi: 10.1371/journal.pone.0050854

Gachon, C. M. M., Sime-Ngando, T., Strittmatter, M., Chambouvet, A., and Kim, G. H. (2010). Algal diseases: spotlight on a black box. Trends Plant Sci. 15, 633-640. doi: 10.1016/j.tplants.2010.08.005 
Ghabrial, S. A., and Suzuki, N. (2009). Viruses of plant pathogenic fungi. Annu. Rev. Phytopathol. 47, 353-384. doi: 10.1146/annurev-phyto-080508-081932

Givskov, M., De Nys, R., Manefield, M., Gram, L., Maximilien, R., Eberl, L., et al. (1996). Eukaryotic interference with homoserine lactone-mediated prokaryotic signalling. J. Bacteriol. 178, 6618-6622.

Godet, L., Fournier, J., Van Katwijk, M. M., Olivier, F., Le Mao, P., and Retière, C. (2008). Before and after wasting disease in common eelgrass Zostera marina along the French Atlantic coasts: a general overview and first accurate mapping. Dis. Aquat. Organ. 79, 249-255. doi: 10.3354/dao01897

Graham, M. H. (2004). Effects of local deforestation on the diversity and structure of southern california giant kelp forest food webs. Ecosystems 7, 341-357. doi: 10.1007/s10021-003-0245-6

Gustavsen, J. A., Winget, D. M., Tian, X., and Suttle, C. A. (2014). High temporal and spatial diversity in marine RNA viruses implies that they have an important role in mortality and structuring plankton communities. Front. Microbiol. 5:703. doi: 10.3389/fmicb.2014.00703

Hall, T. (1999). BioEdit: a user-friendly biological sequence alignment editor and analysis program for Windows 95/98/NT. Nucleic Acids Symp. Ser. 41, 95-98.

Harder, T., Campbell, A. H., Egan, S., and Steinberg, P. D. (2012). Chemical mediation of ternary interactions between marine holobionts and their environment as exemplified by the red alga Delisea pulchra. J. Chem. Ecol. 38, 442-450. doi: 10.1007/s10886-012-0119-5

Harvell, C. D., Kim, K., Burkholder, J. M., Colwell, R. R., Epstein, P. R., Grimes, D. J., et al. (1999). Emerging marine diseases-climate links and anthropogenic factors. Science 285, 1505-1510. doi: 10.1126/science.285.5433.1505

Henry, E. C., and Meints, R. H. (1992). A persistent virus infection in Feldmannia (Phaeophyceae). J. Phycol. 28, 517-526. doi: 10.1111/j.0022-3646.1992. 00517.x

Hewson, I., Button, J. B., Gudenkauf, B. M., Miner, B., Newton, A. L., Gaydos, J. K., et al. (2014). Densovirus associated with sea-star wasting disease and mass mortality. Proc. Natl. Acad. Sci. U.S.A. 111, 17278-17283. doi: 10.1073/pnas.1416625111

Hulo, C., de Castro, E., Masson, P., Bougueleret, L., Bairoch, A., Xenarios, I., et al. (2011). ViralZone: a knowledge resource to understand virus diversity. Nucleic Acids Res. 39, D576-D582. doi: 10.1093/nar/gkq901

Hurwitz, B. L., and Sullivan, M. B. (2013). The Pacific Ocean virome $(\mathrm{POV})$ : a marine viral metagenomic dataset and associated protein clusters for quantitative viral ecology. PLoS ONE 8:e57355. doi: 10.1371/journal.pone.0057355

Kim, S.-Y., Kim, S. R., Oh, M.-J., Jung, S.-J., and Kang, S. Y. (2011). In vitro antiviral activity of red alga, Polysiphonia morrowii extract and its bromophenols against fish pathogenic infectious hematopoietic necrosis virus and infectious pancreatic necrosis virus. J. Microbiol. 49, 102-106. doi: 10.1007/s12275-011$1035-\mathrm{z}$

Lachnit, T., Blümel, M., Imhoff, J. F., and Wahl, M. (2009). Specific epibacterial communities on macroalgae: phylogeny matters more than habitat. Aquat. Biol. 5, 181-186.

Lachnit, T., Fischer, M., Künzel, S., Baines, J. F., and Harder, T. (2013). Compounds associated with algal surfaces mediate epiphytic colonization of the marine macroalga Fucus vesiculosus. FEMS Microbiol. Ecol. 84, 411-420. doi: 10.1111/1574-6941.12071

Lachnit, T., Meske, D., Wahl, M., Harder, T., and Schmitz, R. (2011). Epibacterial community patterns on marine macroalgae are host-specific but temporally variable. Environ. Microbiol. 13, 655-665. doi: 10.1111/j.14622920.2010.02371.x

Lang, A. S., Rise, M. L., Culley, A. I., and Steward, G. F. (2009). RNA viruses in the sea. FEMS Microbiol. Rev. 33, 295-323. doi: 10.1111/j.1574-6976.2008. 00132.x

Lanka, S. T., Klein, M., Ramsperger, U., Müller, D. G., and Knippers, R. (1993). Genome structure of a virus infecting the marine brown alga Ectocarpus siliculosus. Virology 193, 802-811. doi: 10.1006/viro.1993.1189

Largo, D. B., Fukami, K., Nishijima, T., and Ohno, M. (1995). Laboratory-induced development of the ice-ice disease of the farmed red algae Kappaphycus alvarezii and Eucheuma denticulatum (Solieriaceae. Gigartinales, Rhodophyta). J. Appl. Phycol. 7, 539-543. doi: 10.1007/BF00003940

Larsen, J. B., Larsen, A., Thyrhaug, R., Bratbak, G., and Sandaa, R. A. (2008). Response of marine viral populations to a nutrient induced phytoplankton bloom at different pCO2 levels. Biogeosciences 5, 523-533. doi: 10.5194/bg-5523-2008

Letunic, I., Doerks, T., and Bork, P. (2015). SMART: recent updates, new developments and status in 2015. Nucleic Acids Res. 43, D257-D260. doi: 10.1093/nar/gku949

Luan, J.-B., Yao, D.-M., Zhang, T., Walling, L. L., Yang, M., Wang, Y.J., et al. (2013). Suppression of terpenoid synthesis in plants by a virus promotes its mutualism with vectors. Ecol. Lett. 16, 390-398. doi: 10.1111/ele. 12055

Marzinelli, E. M., Campbell, A. H., Zozaya Valdes, E., Vergés, A., Nielsen, S., Wernberg, T., et al. (2015). Continental-scale variation in seaweed hostassociated bacterial communities is a function of host condition, not geography. Environ. Microbiol. 17, 4078-4088. doi: 10.1111/1462-2920. 12972

Matsuo, Y., Imagawa, H., Nishizawa, M., and Shizuri, Y. (2005). Isolation of an algal morphogenesis inducer from a marine bacterium. Science 307, 1598. doi: 10.1126/science. 1105486

Maximilian, R., De Nys, R., Holmström, C., Gram, L., Givskov, M., Crass, K., et al. (1998). Chemical mediation of bacterial surface colonisation by secondary metabolites from the red alga Delisea pulchra. Aquat. Microb. Ecol. 15, 233-246. doi: $10.3354 / \mathrm{ame} 015233$

Mertens, P. (2004). The dsRNA viruses. Virus Res. 101, 3-13. doi: 10.1016/j. virusres.2003.12.002

Nagasaki, K., Tarutani, K., and Yamaguchi, M. (1999). Growth Characteristics of Heterosigma akashiwo virus and its possible use as a microbiological agent for red tide control. Appl. Environ. Microbiol. 65, 898-902.

Nagasaki, K., Tomaru, Y., Katanozaka, N., Shirai, Y., Nishida, K., Itakura, S., et al. (2004). Isolation and characterization of a novel single-stranded rna virus infecting the bloom-forming diatom Rhizosolenia setigera. Appl. Environ. Microbiol. 70, 704-711. doi: 10.1128/AEM.70.2.704-711.2004

Proctor, L. M., and Fuhrman, J. A. (1990). Viral mortality of marine bacteria and cyanobacteria. Nature 343, 60-62. doi: 10.1038/343060a0

Pruitt, K., Brown, G., Tatusova, T., and Maglott, D. (2012). The Reference Sequence (RefSeq) Database. Available at: http://www.ncbi.nlm.nih.gov/books/ NBK21091/ [Accessed August 26, 2015].

Roossinck, M. J. (2012). Plant virus metagenomics: biodiversity and ecology. Annu. Rev. Genet. 46, 359-369. doi: 10.1146/annurev-genet-110711-155600

Rosenberg, E., Koren, O., Reshef, L., Efrony, R., and Zilber-Rosenberg, I. (2007). The role of microorganisms in coral health, disease and evolution. Nat. Rev. Microbiol. 5, 355-362. doi: 10.1038/nrmicro1635

Sanfaçon, H., Wellink, J., Le Gall, O., Karasev, A., van der Vlugt, R., and Wetzel, T. (2009). Secoviridae: a proposed family of plant viruses within the order Picornavirales that combines the families Sequiviridae and Comoviridae, the unassigned genera Cheravirus and Sadwavirus, and the proposed genus Torradovirus. Arch. Virol. 154, 899-907. doi: 10.1007/s00705-00 9-0367-z

Schmieder, R., and Edwards, R. (2011). Fast identification and removal of sequence contamination from genomic and metagenomic datasets. PLOS ONE 6:e17288. doi: 10.1371/journal.pone. 0017288

Schneider, C. A., Rasband, W. S., and Eliceiri, K. W. (2012). NIH Image to ImageJ: 25 years of image analysis. Nat. Methods 9, 671-675. doi: 10.1038/nmeth.2089

Shirai, Y., Tomaru, Y., Takao, Y., Suzuki, H., Nagumo, T., and Nagasaki, K. (2008). Isolation and characterization of a single-stranded RNA virus infecting the marine planktonic diatom Chaetoceros tenuissimus meunier. Appl. Environ. Microbiol. 74, 4022-4027. doi: 10.1128/AEM.00509-08

Steward, G. F., Culley, A. I., Mueller, J. A., Wood-Charlson, E. M., Belcaid, M., and Poisson, G. (2013). Are we missing half of the viruses in the ocean? ISME J. 7, 672-679. doi: 10.1038/ismej.2012.121

Suttle, C. A. (2005). Viruses in the sea. Nature 437, 356-361. doi: 10.1038 /nature 04160

Suttle, C. A., Chan, A. M., and Cottrell, M. T. (1990). Infection of phytoplankton by viruses and reduction of primary productivity. Nature $347,467-469$. doi: $10.1038 / 347467 \mathrm{a} 0$

Takebe, Y., Saucedo, C. J., Lund, G., Uenishi, R., Hase, S., Tsuchiura, T., et al. (2013). Antiviral lectins from red and blue-green algae show potent in vitro and in vivo activity against hepatitis C virus. PLOS ONE 8:e64449. doi: 10.1371/journal.pone.0064449 
Tamura, K., Stecher, G., Peterson, D., Filipski, A., and Kumar, S. (2013). MEGA6: molecular evolutionary genetics analysis version 6.0. Mol. Biol. Evol. 30, 27252729. doi: $10.1093 / \mathrm{molbev} / \mathrm{mst} 197$

Thomas, N. V., and Kim, S.-K. (2013). Beneficial effects of marine algal compounds in cosmeceuticals. Mar. Drugs 11, 146-164. doi: 10.3390/md110 10146

Thompson, J. D., Higgins, D. G., and Gibson, T. J. (1994). CLUSTAL W: improving the sensitivity of progressive multiple sequence alignment through sequence weighting, position-specific gap penalties and weight matrix choice. Nucleic Acids Res. 22, 4673-4680. doi: 10.1093/nar/22.22.4673

Thurber, R. V., Haynes, M., Breitbart, M., Wegley, L., and Rohwer, F. (2009). Laboratory procedures to generate viral metagenomes. Nat. Protoc. 4, 470-483. doi: 10.1038/nprot.2009.10

Tomaru, Y., Mizumoto, H., and Nagasaki, K. (2009a). Virus resistance in the toxic bloom-forming dinoflagellate Heterocapsa circularisquama to single-stranded RNA virus infection. Environ. Microbiol. 11, 2915-2923. doi: 10.1111/j.14622920.2009.02047.x

Tomaru, Y., Takao, Y., Suzuki, H., Nagumo, T., and Nagasaki, K. (2009b). Isolation and characterization of a single-stranded RNA virus infecting the bloomforming diatom Chaetoceros socialis. Appl. Environ. Microbiol. 75, 2375-2381. doi: 10.1128/AEM.02580-08

Tomaru, Y., Takao, Y., Suzuki, H., Nagumo, T., Koike, K., and Nagasaki, K. (2011). Isolation and characterization of a single-stranded DNA virus infecting Chaetoceros lorenzianus Grunow. Appl. Environ. Microbiol. 77, 5285-5293. doi: 10.1128/AEM.00202-11

Tomaru, Y., Toyoda, K., Kimura, K., Hata, N., Yoshida, M., and Nagasaki, K. (2012). First evidence for the existence of pennate diatom viruses. ISME J. 6, 1445-1448. doi: 10.1038/ismej.2011.207

Tuthill, T. J., Groppelli, E., Hogle, J. M., and Rowlands, D. J. (2010). Picornaviruses. Curr. Top. Microbiol. Immunol. 343, 43-89. doi: 10.1007/82_2010_37
Vega Thurber, R. L., Barott, K. L., Hall, D., Liu, H., Rodriguez-Mueller, B., Desnues, C., et al. (2008). Metagenomic analysis indicates that stressors induce production of herpes-like viruses in the coral Porites compressa. Proc. Natl. Acad. Sci. U.S.A. 105, 18413-18418. doi: 10.1073/pnas.0808 985105

Wang, W., Wang, S.-X., and Guan, H.-S. (2012). The antiviral activities and mechanisms of marine polysaccharides: an overview. Mar. Drugs 10, 27952816. doi: 10.3390/md10122795

Williams, G. J., Price, N. N., Ushijima, B., Aeby, G. S., Callahan, S., Davy, S. K. et al. (2014). Ocean warming and acidification have complex interactive effects on the dynamics of a marine fungal disease. Proc. Biol. Sci. 281:20133069. doi: 10.1098/rspb.2013.3069

Willing, B. P., Russell, S. L., and Finlay, B. B. (2011). Shifting the balance: antibiotic effects on host-microbiota mutualism. Nat. Rev. Microbiol. 9, 233-243. doi: $10.1038 /$ nrmicro2536

Zozaya-Valdes, E., Egan, S., and Thomas, T. (2015). A comprehensive analysis of the microbial communities of healthy and diseased marine macroalgae and the detection of known and potential bacterial pathogens. Front. Microbiol. 6:146. doi: $10.3389 /$ fmicb. 2015.00146

Conflict of Interest Statement: The authors declare that the research was conducted in the absence of any commercial or financial relationships that could be construed as a potential conflict of interest.

Copyright (C) 2016 Lachnit, Thomas and Steinberg. This is an open-access article distributed under the terms of the Creative Commons Attribution License (CC BY). The use, distribution or reproduction in other forums is permitted, provided the original author(s) or licensor are credited and that the original publication in this journal is cited, in accordance with accepted academic practice. No use, distribution or reproduction is permitted which does not comply with these terms. 